\title{
Developing Teaching Module of Visual Perception Course
}

\author{
Meirina Lani Anggapuspa \\ Universitas Negeri Surabaya \\ Surabaya, Indonesia \\ meirinaanggapuspa@unesa.ac.id
}

\author{
Arjuna Bangsawan \\ Indonesian Informatics Institute \\ Surabaya, Indonesia \\ juna.bangsawan@gmail.com
}

\begin{abstract}
The changing in curriculum is in line with the changing of KKNI concept in Design study program to fulfill the quality of the alumnae. This is still cannot be implemented due to the lack of appropriate teaching aids. One of them is Visual Perception course whish is on of the compulsory subject as the basic program of knowledge and practice about design. The purpose of this study is to develop teaching module on visual perception course. The research methodology used developmental research method which referred to 4D or Four-D Model development by Thiagarajan. This model has four developmental stages; those are Define, Design, Develop, and Disseminate. The result of the study is the product of teaching aids in the form of teaching module in four chapters. Chapter 1 is visual perception, chapter 2 talks about the elements of visual perception, chapter 3 discussed about the principles of composition in visual perception, and chapter four discussed about working plan of visual perception. Based on the result of the module tested to the students who was taking visual perception course, $72 \%$ stated that the book is good and worth to use.
\end{abstract}

Keywords—teaching module; visual perception; four D model

\section{INTRODUCTION}

Developing teaching materials is one of the compulsory competences which professional educators should have to achieve the teaching competence. Developing teaching materials ideally is a competence that should be mastered by lectures well. Moreover, it should be done in two ways, so there will be good interactions between lectures and students to help the students achieve the competence.

Teaching materials are any materials or course's sources which are created systematically to be used by lectures and students during the course program [1]. Not enough numbers of teaching materials such as module, handout, references books, and so on take part to influence the quality in the lecturing process. The main problem in visual perception course program is not only what are seen using the eves but also about how to explain the perception of what are seen by human. The importance of developing teaching module in visual perception course program is to make the learning process more interesting and focus on the purpose of the learning process [2].

Based on the brief explanation about the problems happened, this study covered three research questions as follows:
1. How is the process to develop teaching module on visual perception course program?

2. How is the quality of the module development on visual perception course program?

\section{METHOD}

\section{A. Research Plan}

This study is a research in education. The scope of the study is the development of teaching materials in the form of module by using developmental research design [3].

\section{B. Developmental Model}

This study focuses on the use of Four-D Model which is suggested by Thiagarajan [4]. There are four steps: define, design, develop, and disseminate.

1) Defining

- Prior analysis about the importance of visual perceptions.

- Students' analysis, the ability of the students to prepare, process and implement the media and sources.

- Task analysis to design assignments for visual perception materials

- Concept analysis to identify main concept to be taught based on the course objectives, learning objectives and learning source analysis.

2) Planning

- Choosing materials

- Choosing teaching aids

- Choosing format

3) Developing

- Expert judgment includes format, language used, content, effective illustration, ease and quality.

- Developmental trial

4) Dissemination process in one of the last steps of the development. Dissemination stage was done to promote the product development to be accepted by the users, individually or in group. 


\section{Data Collection Technique}

The data collection from the result of the quality media product assessment refered to the quality product which is a material can be judged good if it meets the quality aspects, namely: 1) Validity, 2) Practicality, and 3) effectiveness [5]. Data collection refers to:

- Education criteria such as teaching and learning process, curriculum, content, used of words, and languages.

- The appearance of the materials includes colors, letters, and illustration.

- Observation

- Interviews

- Literature study

\section{Instruments}

The instrument used to collect the data was: Instrument of teaching material product assessment by experts, trial instrument, observation sheets, interview instruments, notes, and documentation media.

\section{E. Data Analysis and Validity}

Data analysis in the qualitative study is the process to arrange the data systematically which is gathered trough data collection technique (observation and documentation) and then it is studied and summarized to make it understandable [6]. Data validity used in this study is using data triangulation. The data will be checked trough many sources by comparing and cross checking the information which collected from several sources and different time. It was being matched and crosschecked among many data and sources.

\section{RESULTS AND DISCUSSION}

\section{A. Pre-Post Result Analysis}

Based on the result of the observation to the teaching and learning process of Visual Perception in the last two semesters, there were some obstacles which made the materials are difficult to understand by the students. The factors are; first is the module source materials factor. There is no module source materials of visual perception in written or printed so far. It usually uses books which the number is limited and pictures such as posters which are not classified well.

Second, the factor related to the weakness of the lecturers who take responsibility in this subject. It is related to the readiness of the lecturers to prepare the teaching materials. Lectures are still limited on power point presentation or real pictures.

Third, students factors which is less active during the teaching and learning process. This is because the students do not have adequate literature sources. They only get it mostly form any free sources in the internet. Therefore, the analysis process which should be done appropriately while planning the design or rationalizing their works is not well presented. As a result, the students do the assignments carelessly. As well as in crating their work, they do not finish it maximally because the standard procedure on doing the right work is still blur or unclear for them.

\section{B. Students Analysis Result}

The analysis focused on two aspects, those are a) the level of students' creativity development, b) students' ability to follow the Visual Perception course. After that, students; analysis can be explained as follows:

First, analysis did to the level of cognitive creativity/development and psycomotoric in general. In this stage, students still in their first semester and still do not master many materials especially plan analysis or work analysis.

Second, analysis in the level of students' competence technically, more importantly in changing their perception into works. Generally, students have a good technical ability because only $40 \%$ of the students who technically received the result under the average score.

From both analyses, it can be summed that to construct Visual Perception, students need to have enough knowledge and ability.

\section{Concept Analysis Result}

\section{1) Analysis on study program learning achievement}

Material indication is based on the indicators and aims in the curriculum of visual perception [7]. The activity divided into three, namely a) learning objective analysis, b) indicator and learning goals, c) analyzing the material needs of teaching materials based on indicators that have been determined. Indonesian National Qualification Framework Curriculum on Undergraduate Study Program on Visual Communication Design, program learning outcome has mentioned at least four descriptive parametric, those are 1) ability in attitude, 2) ability in work field, 3) ability in knowledge, and 4) ability in managerial field.

\section{2) Analysis of subject learning outcomes}

Learning outcomes in the Visual Perception course are to foster analytical skills and the expression of perception in the design field. Perceptions conveyed are not only understandable by the designer, but are preferred to be easily understood by consumers. Therefore, it takes deep understanding to design a design that can convey messages easily and attractively. Competencies expected after students take the Visual Perception course in the field of work are: 1) able to prepare material design work or design, 2) able to organize visual elements in the form of designing works by applying perceptions and concepts. While the competencies expected after students take the Visual Perception course in managerial are: 1) able to account for his work on the presentation both individually and in groups, 2) able to communicate Visual Perception based on concepts and ideas / ideas, 3) able to work together in doing work or design, 4) able to document the results of his work in the form of a portfolio of works. 


\section{The Results of the Analysis of the Task}

Assignments developed in the Visual Perception course are based on expected learning outcomes or competencies. The assignments given aim to train students' sensitivity in making and visualizing concepts, students' ability in mastering technicality, analyzing print media advertisements using visual perception theory, semiotics, Gestalt theory, describes the results of visual perception, as well as responsibilities and appreciative attitudes towards the work he has designed.

\section{E. Results of Learning Objectives Formulations}

The purpose of this general learning is to achieve three main parameters in the curriculum that are realized in Visual Perception learning, namely the ability of attitude, knowledge ability, knowledge in the field of work, and managerial ability. These three parameters are then manifested in the indicators / learning achievement of Visual Perception. Students are expected to have these four competency parameters in learning through analysis of the visual work of the poster Public Service Advertisements using Visual Perception theories, creating design works by applying principles and organizing design elements appropriately.

\section{F. Planning Stages}

In general, the designed material is grouped into 3 sections which will be presented in modules. First, it contains perception theory and application, second, namely visual and perception, thirdly perception theory and application.

\section{G. Development Stage}

After conducting a series of activities to validate the instrument / questionnaire that will be used to assess the textbook material, the appearance / graphics of the textbook, and for the trial activities, the results of the instrument validation can be concluded that the results of the instrument validation to assess the feasibility of the Visual Perception module material get a score of $3.63\left(3 \leq R T V_{T K} \leq 4\right)$ in valid category. Based on these results, the validation provides a recommendation that this instrument is proper to use and there is nothing that needs to be revised.

Meanwhile for the results of the validation of the instrument graphics module, it can be concluded that the results of the instrument validation to assess the feasibility of the Visual Perception module get a score of 3.65 ( $3 \leq R T V_{T K}$ $\leq 4)$, in valid category. Based on this evaluation the validation provides recommendations for this instrument to be used to assess the feasibility of instructional media by media experts. The results of the validation recommendations are worth using with a few revisions. Validation notes are revisions of unclear sentences and the same meaning, as well as some writing errors.

Finally, based on the results of the validation of the module trial instrument eligibility, it was concluded that the results of the instrument validation for the Visual Perception module trial by students got a score of $3.67\left(3 \leq R T V_{T K} \leq 4\right)$, in valid category. Based on this evaluation the validation provides recommendations for this instrument to be used for testing the Visual Perception module in a limited group of students.

\section{1) Student Responses to the Oba Test Module}

The trial of the Visual Perception module was only limited to a small group of 15 students from the 2017 Visual Communication Design Study Program. This trial aims to find out students' opinions about the benefits of the Visual Perception module that has been developed. This trial was conducted in the Odd Semester, 2018-2019, precisely on Thursday, September 20, 2018. To get data about the opinions of students, this is done using a questionnaire or test instrument. In this trial at the first meeting students were given the opportunity to read the Visual Perception module that had been distributed.

In general, based on the percentage obtained, the visual perception module book is very good. It can be accepted by students in the learning process and makes it easy to work on assignments as well as understanding the material.

\section{2) The Result of the Students Interview}

This interview is conducted on students who have finished testing a module that was developed. Questions raised focus on three things, namely the quality of the module in terms of usability, content, and appearance of the book. Of the 10 people interviewed, $85 \%$ stated that this module was very helpful to them because so far there has not been a module that specifically discusses visual perception, while there is only a textbook on visual perception.

Meanwhile, in terms of the content of the material, on average they also argue that the material presented is very complete, ranging from understanding perception theory, gestalt theory, aesthetic perception, color theory, to communication theory and simple perception all have coherently sounded out. Meanwhile, in terms of appearance, the modules developed have been very good, both in terms of module covers, illustrations / drawings, color and font choices, and the appropriate module size.

\section{3) Observation Result during Trial}

Based on observations when testing textbooks, it seems that students are following well and really seriously. They were asked to read the tested modules, and were given practice questions to do. Therefore, this trial is independent learning.

\section{4) Distribution Stage}

In this study the deployment or disseminate phase was not included in the planned research module development phase. This is because this research is limited by time, so it is not possible to carry out the stages of dissemination and evaluation widely.

\section{5) Teaching Material Products in the form of Final} Textbooks

After going through revisions based on input from material experts who are competent in providing an assessment of the content of materials and writing, and design experts who are competent in the field of design and layout, the module 
development research products in the form of Visual Perception modules can be completed.

\section{CONCLUSION}

The teaching materials developed have a good quality if it meets the aspects 1) validity, 2) practicality, and 3) effectiveness. Based on these criteria, the result from the development stage can be described as instrument validation stage to know the product's validity which is going to be developed, assessment stage product development by experts to know the practicality of development product and media trial by students to get the feedback from the students.

Visual Perception module which was being developed is actually has many advantages, but there are some points need to be revised. The book's cover should have attractiveness by emphasizing the aspects or interest/main attention. The typography size for the title needs to be made bigger to get the attention or as differentiator. Generally the position of the page numbers has been good, but the font or subtitle letters, texts or content and captions or information of figures should be distinguished in size.

\section{REFERENCES}

[1] P.P. Purwanto, Penulisan Bahan Ajar. Jakarta: Dirjen Dikti Depdiknas, 2001.

[2] Sungkono, et al. Pengembangan Bahan Ajar. Yogyakarta: FIP UNY, 2003.

[3] Gusmiyeni, et al. "Pengembangan Bahan Ajar Tari Dana Syarah Untuk SMP Kelas VIII Menggunakan Model Pembelajaran Simulasi,” Jurnal Tekno-Pedagogi, Vol. 3, No. 1, March 2013. pp. 1-11

[4] Thiagarajan, S; Semmel, D.S; \& Semmel, M.I. Instructional Development for Training Teachers of Exceptional Children: A Sourcebook. Indiana: Indiana University. 1974.

[5] Tian Belawati, et al. Pengembangan Bahan Ajar . Jakarta: Pusat Penerbitan UT, 2003.

[6] Sugiyono, Metode Penelitian Kombinasi, Bandung: Alfabeta, 2011.

[7] Irwan, "Pengembangan Bahan Ajar Seni Rupa Bermedia Powerpoint Kelas X SMK,” Jurnal Tekno-Pedagogi Vol. 2, No. 2, September 2012: pp. $1-12$ 